\title{
The Effect of Varying Water Soluble Components on the Radiative Forcing of Continental Average Aerosols
}

\author{
Bello Idrith Tijjani ${ }^{1}$, Bello ${ }^{2}$ M,A. U.Muhammad,M.G Ahmad, R.S Said ${ }^{1}$ \\ 1.Department of Physics,Bayero University, Kano, Nigeria \\ 2.Department of Physics, Federal University, Gusau, Nigeria
}

\begin{abstract}
This work embodies the results of the effect of the water soluble components on the radiative forcing of continental average aerosols, from aerosol data extracted from optical properties of aerosols and cloud (OPAC) 4.0 software package using FORTRAN program to model the effect of water soluble on optical depth, asymmetric parameter, scattering and absorption coefficients at the spectral range of $(0.25-0.80 \mu \mathrm{m})$ and at eight relative humidities $(0 \%, 50 \%, 70 \%, 80 \%, 90 \%, 95 \%, 98 \% \& 99 \%)$. The concentration of water soluble was varied while concentrations of water insoluble and soot were kept constant. The optical parameters were used to compute numerically the radiative forcing using the concept of chylek and wong, the Angstrom exponent $(\alpha)$, turbidity $(\beta)$ and Curvature $\left(\alpha_{2}\right)$ using regression analysis with SPSS 20.0 IBM. From the results obtained it was observed that $\alpha$ which determined the particle size distribution is greater than 1.0 at (0\%-95\%) RHs and it signifies that fine accumulation mode is the most dominant but at deliquescence points (98\%-99\%) RHs $\alpha$ is less than 1.0 and this show the present of coarse mode. The curvature $\alpha_{2}$ which gives additional information of particle mode distributions was negative at all RHs indicating the dominance of fine mode particles. The optical depth of the atmospheric aerosols were determined for each model and analyzed graphically, the results have shown the clear decrease in size with increase in wavelength, but increases with increase in RHs. The turbidity $\beta$ increase with increases in concentration number of water soluble signifies the increases in aerosol loading which show decrease in visibility of the atmosphere. The analysis further shows that these aerosols have monomodal type of particle distributions.
\end{abstract}

Keywords: Angstrom exponent, Curvature, Optical depth, Radiative forcing, Turbidity.

DOI: $10.7176 /$ APTA/79-04

Publication date:September $30^{\text {th }} 2019$

\section{Introduction}

Atmospheric aerosols, which are defined as liquid or solid particles suspended in a gas (Seinfeld and Pandis, 2006), are tiny and usually invisible to our eyes. Nevertheless, they have an immense impact on our health and on our global climate.

Aerosol particles in the atmosphere which comprised both water soluble and insoluble aerosols, affect the earth's radiation balance in both direct and indirect ways. The direct effect is influenced by the hygroscopicity of the aerosol particles, while the indirect is the tendency for cloud formation and resulting cloud properties all due to changes in Relative humidity (Solomon, S.et al., 2007; Tijjani et al., 2014).

Aerosols scatter and absorb solar radiation, and, by doing so, they directly influence the Earth's radiation budget. In addition, anthropogenic aerosol particles modify cloud properties, causing, e.g., brighter clouds with longer lifetimes and changed precipitation behavior (Lohmann and Leck, 2005; Ramaswamy et al., 2001; Twomey, 1977).. The net effect of anthropogenic aerosols on the Earth's climate is cooling, in contrast to greenhouse gases, which have a warming effect (P.zieger et al.,2013). However, the Intergovernmental Panel on Climate Change (IPCC, 2007) concludes that the high uncertainty in the net radiative forcing of all main climate agents is mainly dominated by the large uncertainty in the aerosol radiative forcing. This is mainly caused by the high temporal, spatial, and compositional variability of the aerosol and the poorly understood and quantified aerosol effects.

The water-soluble part of aerosol particles originates from gas to particle conversion and consist of various kinds of sulphate, nitrates and others also organic, water soluble substances. Thus, it contains more than only the sulphate aerosol that is often used to describe anthropogenic aerosol (Hess et al.,1998). Most of the earliest investigations on direct aerosol forcing focused on sulphate aerosol because of their importance as an anthropogenic aerosol component (Charlson et al.,1992, Kiehl and Briegleb, 1993). Sulphate particle is an important component of atmospheric aerosols. Sulphate aerosols are capable of modifying the climate not only by scattering incoming sunlight back to space (direct effect) but also by altering the properties of clouds (indirect effect) (Verma et al.,2012).

The aim of this paper is to determine the effect of varying water soluble component on radiative forcing of continental average aerosols on three components of aerosols extracted from OPAC 4.0 software data set at the spectral range of $0.25-0.80 \mu \mathrm{m}$ and at eight relative humidity of $(0 \%, 50 \%, 70 \%, 80 \%, 90 \%, 95 \%, 98 \%$ and $99 \%)$. 


\section{Methodology}

The data used for continental average aerosols shown in Table 1: were extracted from the optical properties of aerosols and clouds (OPAC) 4.0 dataset. Mixtures of three components were used to describe continental average. They are: water soluble components, consist of scattering aerosols, which are hygroscopic in nature, such as sulfates and nitrates present in anthropogenic pollution, while water insoluble and soot are considered not soluble in water and therefore the particles are assumed not to grow with increasing relative humidity.

Table 1; Components of continental average aerosols with varying water soluble concentrations $\mathrm{N}_{\mathrm{i}}\left(1 / \mathrm{cm}^{3}\right)$ (Hess et al., 1998).

\begin{tabular}{|l|l|l|l|l|l|}
\hline Components & Model 1 & Model 2 & Model 3 & Model 4 & Model 5 \\
\hline Water soluble & $\mathbf{7 0 0 0}$ & $\mathbf{7 1 0 0}$ & $\mathbf{7 2 0 0}$ & $\mathbf{7 3 0 0}$ & $\mathbf{7 4 0 0}$ \\
\hline Water insoluble & 0.4 & 0.4 & 0.4 & 0.4 & 0.4 \\
\hline Soot & 8300 & 8300 & 8300 & 8300 & 8300 \\
\hline
\end{tabular}

Table 1 describes the concentrations of continental average aerosols simulated with varying water soluble (non-spherical) component.

\section{Radiative Forcing Model}

To estimate the radiative forcing using simple model, we adopt the approach used by

Chylek and Wong (1995) from which the global averaged direct aerosol radiative forcing $\Delta \mathrm{F}_{\mathrm{R}}$ is given by:

$$
\Delta F_{R}=-\frac{s_{O}}{4} T_{a t m}^{2}(1-N)\left\{(1-A)^{2} 2 \beta \tau s c a-4 A \tau_{\text {abs }}\right\}
$$

where $\mathrm{S}_{0}$ is the solar constant, $\mathrm{T}_{\mathrm{atm}}$ is the transmittance of the atmosphere above the aerosol layer, $\mathrm{N}_{\text {cloud }}$ is the fraction of the sky covered by clouds, $\tau$ is the aerosol optical depth, A is the average single scattering albedo of the aerosol layer, and $\beta$ is the fraction of radiation scattered by aerosol into the atmosphere while $\tau s c a$ and $\tau_{a b s}$ are the aerosol layer scattering and absorption optical thickness respectively. The above expression gives the radiative forcing due to the change of reflectance of the earth-aerosol system. The up-scattering fraction is calculated using an approximate relation (Sagan and Pollack,1967)

$$
\beta=\frac{1}{2}(1-g)
$$

Where $\mathrm{g}$ is the asymmetry parameter of the aerosol layer. The model parameters are assigned the following values: $\mathrm{S}_{0}=1368 \mathrm{Wm}^{-2}, \mathrm{~T}_{\mathrm{atm}}=0.79$, (penner J.E et al.,1992) and cloudness $\mathrm{N}=0.6$. The global averaged albedo $\mathrm{A}=0.22$ over land and $\mathrm{A}=0.06$ over the ocean with $80 \%$ of aerosols being over the land.

\section{Estimation of Angstrom Coefficients}

The spectral behavior of the aerosols optical depth $(\tau)$ that expresses the spectral dependence of any of the optical parameters with the wavelength of light $(\lambda)$ as inverse power law (Angstrom, 1961; Angstrom, 1929):

$$
\tau(\lambda)=\beta \lambda^{-\alpha}
$$

The wavelength dependence of $\tau(\lambda)$ can be characterized by the Ångström parameter, which is a coefficient of the following regression:

$$
\ln \tau(\lambda)=-\alpha \ln (\lambda)+\ln \beta
$$

Where $\beta$ and $\alpha$ are the turbidity coefficient and Ångström exponent (Liou, 2002; O’Neill and Roer,1993) $\alpha$ is related to the size distribution.

The Angstrom exponent itself varies with wavelength, and a more precise empirical relationship between aerosol extinction and wavelength is obtained with a 2nd-order polynomial (King and Byrne, 1976) as:

$$
\ln \tau(\lambda)=\alpha_{2}(\ln \lambda)_{2}+\alpha_{1} \ln \lambda+\ln \beta
$$

The coefficient $\alpha_{2}$ accounts for "curvature" often observed in Sun photometry measurements. In case of negative curvature $\left(\alpha_{2}<0\right.$, convex type curves $)$ the rate of change of $\alpha$ is more significant at the longer wavelengths, while positive curvature $\left(\alpha_{2}>0\right.$, concave type curves) the rate of change of $\alpha$ is more significant at the shorter wavelengths. Eck et al., (1999) reported the existence of negative curvatures for fine mode and positive curvatures for significant contribution by coarse mode particles in the size distribution.

\section{Results and Discussion}

The results of Angstrom exponent and radiative forcing for water soluble component of atmospheric aerosols models extracted from optical properties of aerosols and cloud (OPAC) 4.0. The effect of water soluble (WASO) component on optical depth, scattering coefficient, absorption coefficient, scattering coefficient and asymmetry parameter at spectral range of 0.25 to $0.80 \mu \mathrm{m}$ near Ultraviolet to Visible region for eight relative humidities (RHs) $(0 \%, 50 \%, 70 \%, 80 \%, 90 \%, 95 \%, 98 \%, 99 \%)$ of continental average aerosols were obtain and shown on the tables and figures below. 
Table 1a: Linear results of the regression analysis for model 1 of table 1.

\begin{tabular}{|l|l|l|l|l|l|l|}
\hline RH(\%) & $\mathrm{R}^{2}$ & Sig & $\alpha$ & Sig & B & Sig \\
\hline 0 & 0.9911 & $1.34 \mathrm{E}-11$ & 1.2019 & $1.34 \mathrm{E}-11$ & 0.0659 & $3.76 \mathrm{E}-16$ \\
\hline 50 & 0.9900 & $2.48 \mathrm{E}-11$ & 1.2057 & $2.48 \mathrm{E}-11$ & 0.0974 & $3.39 \mathrm{E}-15$ \\
\hline 70 & 0.9892 & $3.69 \mathrm{E}-11$ & 1.1910 & $3.69 \mathrm{E}-11$ & 0.1183 & $1.07 \mathrm{E}-14$ \\
\hline 80 & 0.9883 & $5.38 \mathrm{E}-11$ & 1.1714 & $5.38 \mathrm{E}-11$ & 0.1416 & $3.19 \mathrm{E}-14$ \\
\hline 90 & 0.9864 & $1.15 \mathrm{E}-10$ & 1.1192 & $1.15 \mathrm{E}-10$ & 0.2023 & $3.24 \mathrm{E}-13$ \\
\hline 95 & 0.9836 & $2.90 \mathrm{E}-10$ & 1.0437 & $2.90 \mathrm{E}-10$ & 0.3056 & $8.02 \mathrm{E}-12$ \\
\hline 98 & 0.9786 & $1.11 \mathrm{E}-09$ & 0.9244 & $1.11 \mathrm{E}-09$ & 0.5359 & $5.18 \mathrm{E}-09$ \\
\hline 99 & 0.9740 & $2.95 \mathrm{E}-09$ & 0.8386 & $2.95 \mathrm{E}-09$ & 0.7779 & $2.49 \mathrm{E}-05$ \\
\hline
\end{tabular}

Base on the content of Table $1 \mathrm{a}$ and by observing the values of $\mathrm{R}^{2}$ and the significances of the entire coefficient, it can be said that the data fitted the equation model very well. The values of $\alpha$ reflects the dominance of fine/accumulation modes, but at deliquescence point (98-99\%) RH it is less than 1 signifies the presence of coarse mode particles as fine mode are act as cloud condensation nuclei. But $\beta$ (turbidity coefficient) increase with the increase in RHs indicating that the aerosol loading also increases with the increase in RH.

Table 1b: Quadratic results of the regression analysis for model 1 of table 1

\begin{tabular}{|l|l|l|l|l|l|l|l|l|}
\hline RH(\%) & $R^{2}$ & Sig & $\alpha_{1}$ & Sig & $\alpha_{2}$ & Sig & $\beta$ & Sig \\
\hline 0 & 0.9999 & $6.05 \mathrm{E}-18$ & -1.7372 & $8.84 \mathrm{E}-14$ & -0.3423 & $2.73 \mathrm{E}-09$ & 0.0560 & $5.67 \mathrm{E}-20$ \\
\hline 50 & 0.9999 & $1.03 \mathrm{E}-19$ & -1.7800 & $1.26 \mathrm{E}-15$ & -0.3673 & $2.67 \mathrm{E}-11$ & 0.0817 & $3.56 \mathrm{E}-21$ \\
\hline 70 & 1.0000 & $2.40 \mathrm{E}-20$ & -1.7821 & $2.60 \mathrm{E}-16$ & -0.3780 & $4.34 \mathrm{E}-12$ & 0.0988 & $1.51 \mathrm{E}-21$ \\
\hline 80 & 1.0000 & $6.47 \mathrm{E}-21$ & -1.7758 & $6.26 \mathrm{E}-17$ & -0.3865 & $8.32 \mathrm{E}-13$ & 0.1178 & $7.15 \mathrm{E}-22$ \\
\hline 90 & 1.0000 & $6.77 \mathrm{E}-22$ & -1.7433 & $5.18 \mathrm{E}-18$ & -0.3991 & $4.39 \mathrm{E}-14$ & 0.1672 & $2.51 \mathrm{E}-22$ \\
\hline 95 & 1.0000 & $5.44 \mathrm{E}-23$ & -1.6831 & $3.09 \mathrm{E}-19$ & -0.4089 & $1.54 \mathrm{E}-15$ & 0.2514 & $1.12 \mathrm{E}-22$ \\
\hline 98 & 1.0000 & $2.85 \mathrm{E}-23$ & -1.5735 & $1.02 \mathrm{E}-19$ & -0.4151 & $2.42 \mathrm{E}-16$ & 0.4396 & $2.14 \mathrm{E}-21$ \\
\hline 99 & 1.0000 & $9.15 \mathrm{E}-23$ & -1.4895 & $2.28 \mathrm{E}-19$ & -0.4163 & $3.22 \mathrm{E}-16$ & 0.6377 & $6.62 \mathrm{E}-19$ \\
\hline
\end{tabular}

From Table $1 \mathrm{~b}$ and by observing the values of $\mathrm{R}^{2}$ and the significances of all the coefficients, it can be said that the data fitted the equation model very well. The negative sign of $\alpha_{2}$, shows that this is monomodal and is dominated by fine mode particles. The increase in the values of $\alpha_{2}$, with RH shows the increase in the concentrations of fine particles. But $\beta$ (turbidity coefficient) increase with the increase in RH indicating that the aerosol loading also increases with the increase in $\mathrm{RH}$ and visibility of atmosphere reduce.

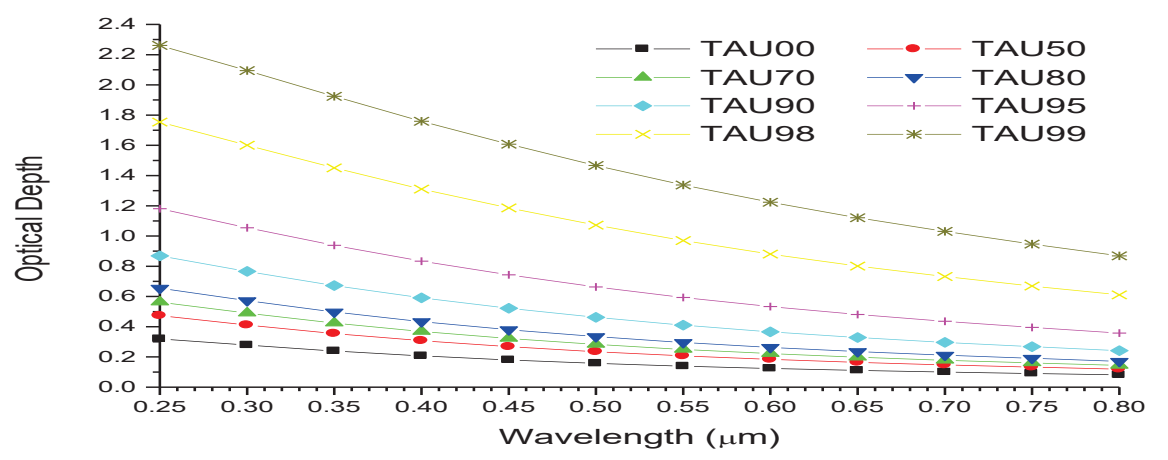

Figure 1(a). A graph of optical depth against wavelength for continental average

From the plots of figure 1a, it can seen that the optical depth follows a relatively smooth decrease with increase in wavelength for all relative humidities, though increases as the number density of water soluble increases, indicating more scattering in the forward direction verifying the effect of cooling. 


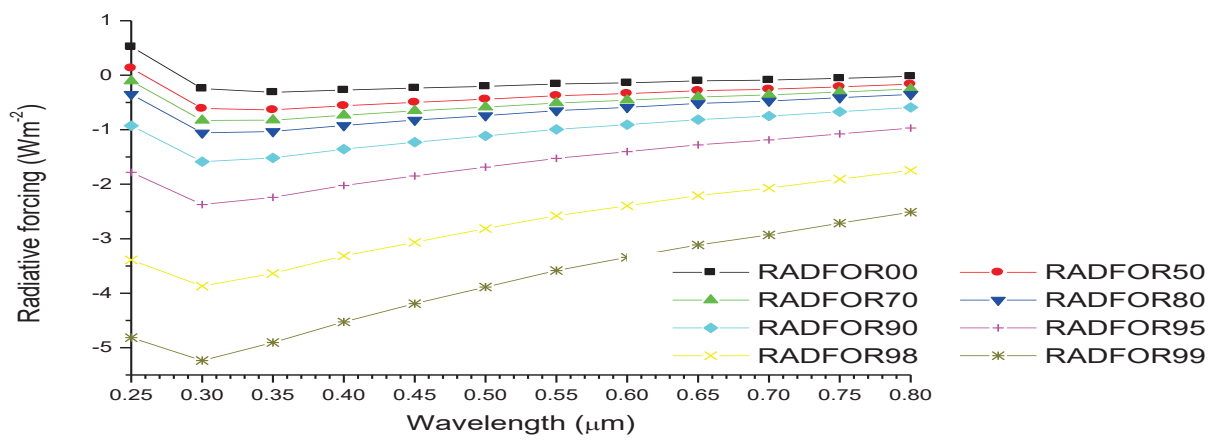

Figure 1(b). A graph of radiative forcing against wavelength for continental average

From the plots of figure $1 \mathrm{~b}$, the warming effects occurred at $0-50 \%$ RHs. While cooling begins to occur at $70 \%$ and increase with increase in relative humidities, and this show that water soluble due to high percentage of sulphate has a relatively high scattering coefficient.

Table 2a: Linear results of the regression analysis for model 2 of table 1

\begin{tabular}{|l|l|l|l|l|l|l|}
\hline $\mathrm{RH}(\%)$ & $\mathrm{R}^{2}$ & Sig & $\alpha$ & Sig & B & Sig \\
\hline 0 & 0.9911 & $1.39 \mathrm{E}-11$ & 1.2031 & $1.39 \mathrm{E}-11$ & 0.0666 & $4.09 \mathrm{E}-16$ \\
\hline 50 & 0.9899 & $2.55 \mathrm{E}-11$ & 1.2064 & $2.55 \mathrm{E}-11$ & 0.0985 & $3.68 \mathrm{E}-15$ \\
\hline 70 & 0.9891 & $3.81 \mathrm{E}-11$ & 1.1919 & $3.81 \mathrm{E}-11$ & 0.1197 & $1.17 \mathrm{E}-14$ \\
\hline 80 & 0.9883 & $5.49 \mathrm{E}-11$ & 1.1720 & $5.49 \mathrm{E}-11$ & 0.1434 & $3.48 \mathrm{E}-14$ \\
\hline 90 & 0.9864 & $1.17 \mathrm{E}-10$ & 1.1196 & $1.17 \mathrm{E}-10$ & 0.2049 & $3.57 \mathrm{E}-13$ \\
\hline 95 & 0.9836 & $2.95 \mathrm{E}-10$ & 1.0438 & $2.95 \mathrm{E}-10$ & 0.3097 & $9.12 \mathrm{E}-12$ \\
\hline 98 & 0.9787 & $1.09 \mathrm{E}-09$ & 0.9246 & $1.09 \mathrm{E}-09$ & 0.5432 & $6.31 \mathrm{E}-09$ \\
\hline 99 & 0.9740 & $2.98 \mathrm{E}-09$ & 0.8383 & $2.98 \mathrm{E}-09$ & 0.7888 & $4.07 \mathrm{E}-05$ \\
\hline
\end{tabular}

From Table $2 \mathrm{a}$, it can be observed that the values of $\mathrm{R}^{2}$ and significances of all the coefficients, it can be said that the data fitted the equation model very well. The value $\alpha$ increases with the RHs $(0 \%-50 \%)$ and this signifies the increase in the dominance of fine/accumulation particles, but at deliquescence point (98-99\%) RH it is less than 1 signifies the presence of coarse mode particles as fine mode are act as cloud condensation nuclei. But $\beta$ (turbidity coefficient) increase with the increase in RHs indicating that the aerosol loading also increases with the increase in RH.

Table 2b: Quadratic results of the regression analysis for model 2 of table 1

\begin{tabular}{|l|l|l|l|l|l|l|l|l|}
\hline RH(\%) & $\mathrm{R}^{2}$ & Sig & $\alpha_{1}$ & Sig & $\alpha_{2}$ & Sig & $\beta$ & Sig \\
\hline 0 & 0.9999 & $5.33 \mathrm{E}-18$ & -1.7412 & $7.70 \mathrm{E}-14$ & -0.3441 & $2.32 \mathrm{E}-09$ & 0.0565 & $5.19 \mathrm{E}-20$ \\
\hline 50 & 0.9999 & $1.09 \mathrm{E}-19$ & -1.7826 & $1.32 \mathrm{E}-15$ & -0.3685 & $2.76 \mathrm{E}-11$ & 0.0826 & $3.93 \mathrm{E}-21$ \\
\hline 70 & 1.0000 & $1.87 \mathrm{E}-20$ & -1.7855 & $2.01 \mathrm{E}-16$ & -0.3796 & $3.28 \mathrm{E}-12$ & 0.0999 & $1.23 \mathrm{E}-21$ \\
\hline 80 & 1.0000 & $4.69 \mathrm{E}-21$ & -1.7781 & $4.51 \mathrm{E}-17$ & -0.3876 & $5.92 \mathrm{E}-13$ & 0.1192 & $5.47 \mathrm{E}-22$ \\
\hline 90 & 1.0000 & $7.20 \mathrm{E}-22$ & -1.7447 & $5.49 \mathrm{E}-18$ & -0.3998 & $4.62 \mathrm{E}-14$ & 0.1693 & $2.85 \mathrm{E}-22$ \\
\hline 95 & 1.0000 & $6.94 \mathrm{E}-23$ & -1.6843 & $3.92 \mathrm{E}-19$ & -0.4096 & $1.93 \mathrm{E}-15$ & 0.2547 & $1.56 \mathrm{E}-22$ \\
\hline 98 & 1.0000 & $2.99 \mathrm{E}-23$ & -1.5726 & $1.08 \mathrm{E}-19$ & -0.4144 & $2.58 \mathrm{E}-16$ & 0.4457 & $2.62 \mathrm{E}-21$ \\
\hline 99 & 1.0000 & $7.80 \mathrm{E}-23$ & -1.4898 & $1.93 \mathrm{E}-19$ & -0.4166 & $2.71 \mathrm{E}-16$ & 0.6466 & $7.45 \mathrm{E}-19$ \\
\hline
\end{tabular}

From Table $2 \mathrm{~b}$ and by observing the values of $\mathrm{R}^{2}$ and the significances of all the coefficients, it can be said that the data fitted the equation model very well. The negative sign of $\alpha_{2}$, shows that this is monomodal and is dominated by fine mode particles. The increase in the values of $\alpha_{2}$, with RH shows the increase in the concentrations of fine particles. But $\beta$ (turbidity coefficient) increase with the increase in RH indicating that the aerosol loading also increases with the increase in RH. 


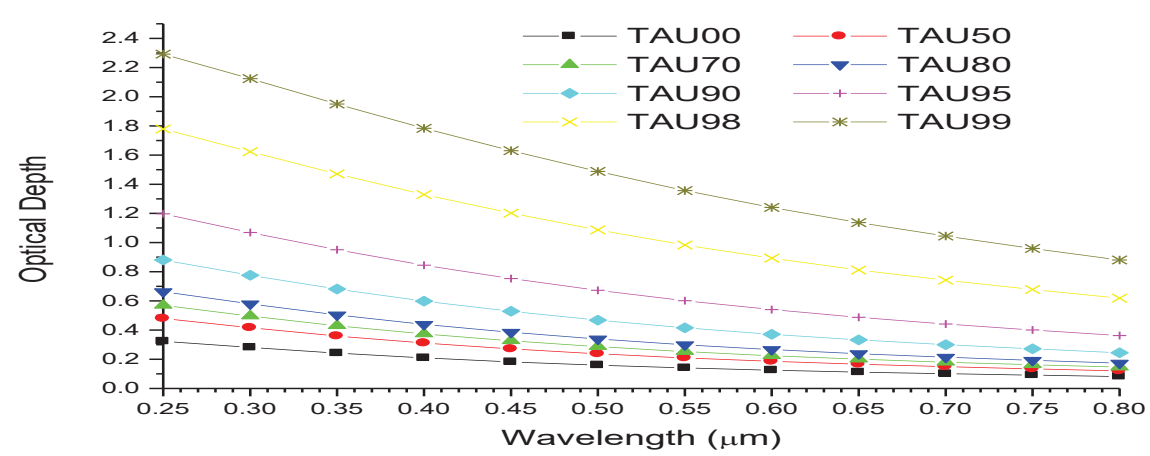

Figure 3.2(a), A graph of optical depth against wavelength for continental average.

From the plots of figure 4.12a, it can seen that the optical depth follows a relatively smooth decrease with increase in wavelength for all relative humidities, though increases as the number density of water soluble increases, indicating more scattering in the forward direction verifying the effect of cooling.

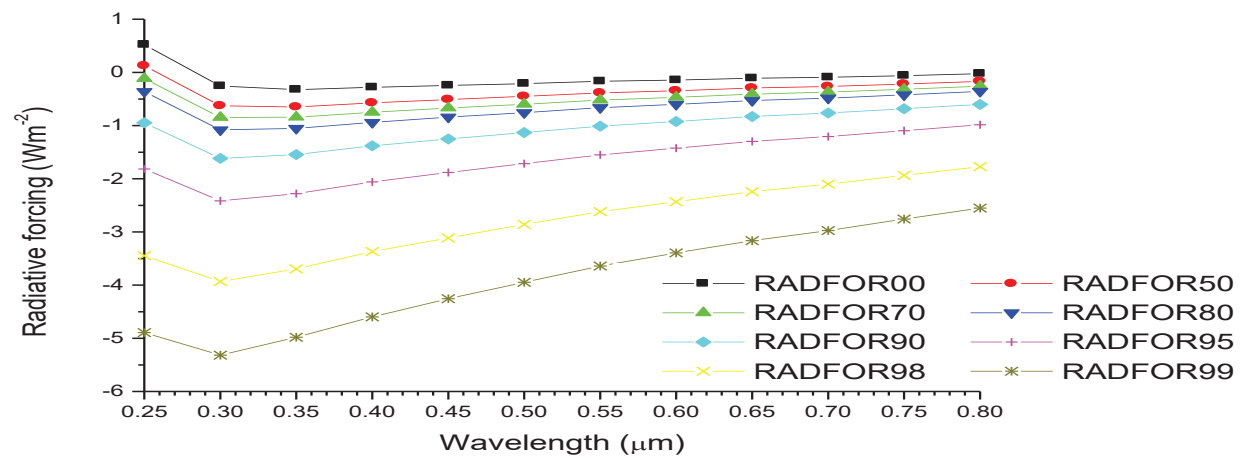

Figure 2(b). A graph of radiative forcing against wavelength for continental average.

From the plots of figure $2 b$, the warming effects occurred at $0-50 \%$ RHs. While cooling begins to occur at $70 \%$ and increase with increase in relative humidities and this show that water soluble due to high percentage of sulphate has a relatively high scattering coefficient.

Table 3a: Linear results of the regression analysis for model 3 of table 1

\begin{tabular}{|l|l|l|l|l|l|l|}
\hline RH(\%) & $R^{2}$ & Sig & $\alpha$ & Sig & B & Sig \\
\hline 0 & 0.9910 & $1.43 \mathrm{E}-11$ & 1.2047 & $1.43 \mathrm{E}-11$ & 0.0672 & $4.39 \mathrm{E}-16$ \\
\hline 50 & 0.9899 & $2.57 \mathrm{E}-11$ & 1.2074 & $2.57 \mathrm{E}-11$ & 0.0996 & $3.93 \mathrm{E}-15$ \\
\hline 70 & 0.9891 & $3.89 \mathrm{E}-11$ & 1.1926 & $3.89 \mathrm{E}-11$ & 0.1211 & $1.27 \mathrm{E}-14$ \\
\hline 80 & 0.9882 & $5.55 \mathrm{E}-11$ & 1.1726 & $5.55 \mathrm{E}-11$ & 0.1451 & $3.76 \mathrm{E}-14$ \\
\hline 90 & 0.9863 & $1.18 \mathrm{E}-10$ & 1.1200 & $1.18 \mathrm{E}-10$ & 0.2075 & $3.92 \mathrm{E}-13$ \\
\hline 95 & 0.9836 & $2.95 \mathrm{E}-10$ & 1.0442 & $2.95 \mathrm{E}-10$ & 0.3138 & $1.02 \mathrm{E}-11$ \\
\hline 98 & 0.9786 & $1.11 \mathrm{E}-09$ & 0.9246 & $1.11 \mathrm{E}-09$ & 0.5506 & $8.02 \mathrm{E}-09$ \\
\hline 99 & 0.9739 & $2.99 \mathrm{E}-09$ & 0.8385 & $2.99 \mathrm{E}-09$ & 0.7997 & $6.70 \mathrm{E}-05$ \\
\hline
\end{tabular}

Through the knee observation of Table $3.3 \mathrm{a}$ and by observing the values of $\mathrm{R}^{2}$ and significances of all the coefficients, it can be said that the data fitted the equation model very well. The value $\alpha$ increases with the RHs $(0 \%-\% 50 \%)$ and this signifies the increase in the dominance of fine/accumulation particles, but at deliquescence point (98-99\%) RH it is less than 1 signifies the presence of coarse mode particles as fine mode are act as cloud condensation nuclei. But $\beta$ (turbidity coefficient) increase with the increase in RHs indicating that the aerosol loading also increases with the increase in $\mathrm{RH}$. 
Table 3b: Quadratic results of the regression analysis for model 3 of table 1

\begin{tabular}{|l|l|l|l|l|l|l|l|l|}
\hline RH(\%) & $\mathrm{R}^{2}$ & Sig & $\alpha_{1}$ & Sig & $\alpha_{2}$ & Sig & $\beta$ & Sig \\
\hline 0 & 0.9999 & $5.06 \mathrm{E}-18$ & -1.7447 & $7.26 \mathrm{E}-14$ & -0.3453 & $2.16 \mathrm{E}-09$ & 0.0570 & $5.12 \mathrm{E}-20$ \\
\hline 50 & 0.9999 & $8.34 \mathrm{E}-20$ & -1.7848 & $1.00 \mathrm{E}-15$ & -0.3693 & $2.09 \mathrm{E}-11$ & 0.0835 & $3.15 \mathrm{E}-21$ \\
\hline 70 & 1.0000 & $1.60 \mathrm{E}-20$ & -1.7879 & $1.70 \mathrm{E}-16$ & -0.3807 & $2.75 \mathrm{E}-12$ & 0.1010 & $1.11 \mathrm{E}-21$ \\
\hline 80 & 1.0000 & $4.59 \mathrm{E}-21$ & -1.7796 & $4.40 \mathrm{E}-17$ & -0.3882 & $5.74 \mathrm{E}-13$ & 0.1206 & $5.65 \mathrm{E}-22$ \\
\hline 90 & 1.0000 & $5.14 \mathrm{E}-22$ & -1.7460 & $3.91 \mathrm{E}-18$ & -0.4003 & $3.27 \mathrm{E}-14$ & 0.1714 & $2.18 \mathrm{E}-22$ \\
\hline 95 & 1.0000 & $6.77 \mathrm{E}-23$ & -1.6850 & $3.82 \mathrm{E}-19$ & -0.4098 & $1.88 \mathrm{E}-15$ & 0.2580 & $1.66 \mathrm{E}-22$ \\
\hline 98 & 1.0000 & $4.36 \mathrm{E}-23$ & -1.5742 & $1.56 \mathrm{E}-19$ & -0.4154 & $3.69 \mathrm{E}-16$ & 0.4516 & $4.43 \mathrm{E}-21$ \\
\hline 99 & 1.0000 & $1.48 \mathrm{E}-22$ & -1.4901 & $3.67 \mathrm{E}-19$ & -0.4167 & $5.16 \mathrm{E}-16$ & 0.6555 & $1.89 \mathrm{E}-18$ \\
\hline
\end{tabular}

From Table $3 \mathrm{~b}$ and by observing the values of $\mathrm{R}^{2}$ and the significances of all the coefficients, it can be said that the data fitted the equation model very well. The negative sign of $\alpha_{2}$, shows that this is monomodal and is dominated by fine mode particles. The increase in the values of $\alpha_{2}$, with RH shows the increase in the concentrations of fine particles. But $\beta$ (turbidity coefficient) increase with the increase in $\mathrm{RH}$ indicating that the aerosol loading also increases with the increase in $\mathrm{RH}$.

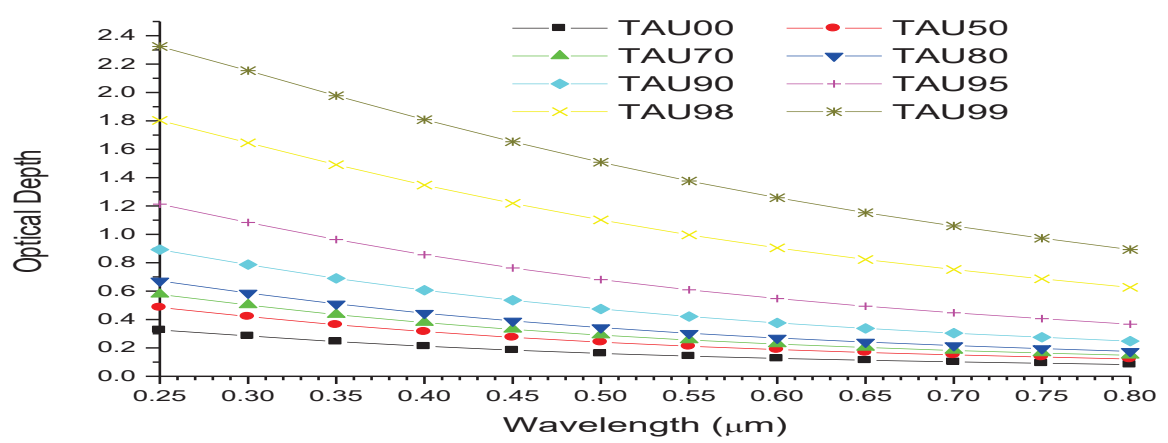

Figure 3(a). A graph of optical depth against wavelength for continental average.

From the plots of figure $3 \mathrm{a}$, it can seen that the optical depth follows a relatively smooth decrease with increase in wavelength for all relative humidities, though increases as the number density of water soluble increases, indicating more scattering in the forward direction verifying the effect of cooling.

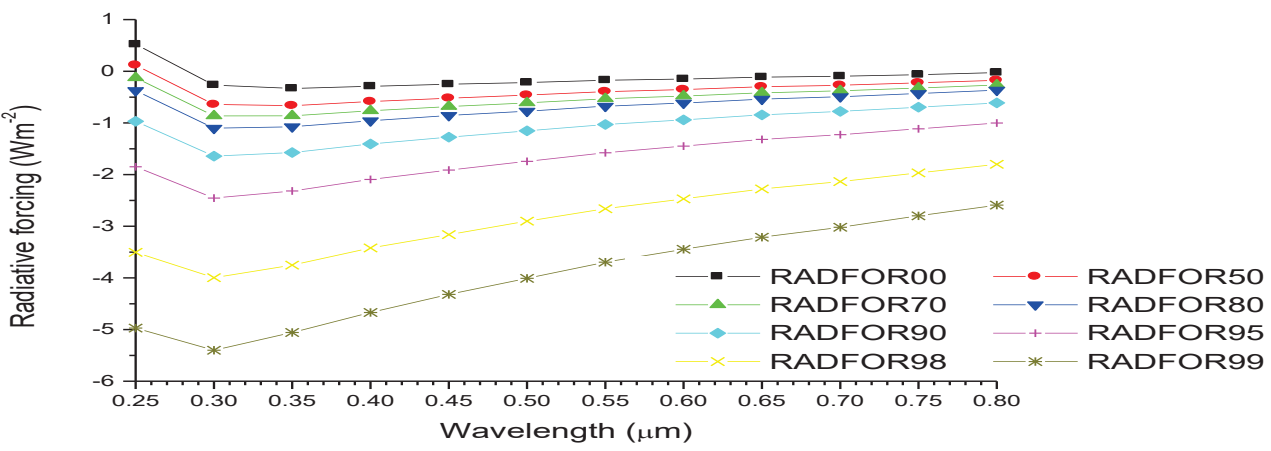

Figure 3(b). A graph of radiative forcing against wavelength for continental average.

From the plots of figure $3 \mathrm{~b}$, the warming effects occurred at $0-50 \%$ RHs. While cooling begins to occur at $70 \%$ and increase with increase in relative humidities and this show that water soluble due to high percentage of sulphate has a relatively high scattering coefficient. 
Table 4a: Linear results of the regression analysis for model 4 of table 1

\begin{tabular}{|l|l|l|l|l|l|l|}
\hline RH(\%) & $R^{2}$ & Sig & $\alpha$ & Sig & B & Sig \\
\hline 0 & 0.9910 & $1.48 \mathrm{E}-11$ & 1.2058 & $1.48 \mathrm{E}-11$ & 0.0679 & $4.78 \mathrm{E}-16$ \\
\hline 50 & 0.9898 & $2.67 \mathrm{E}-11$ & 1.2084 & $2.67 \mathrm{E}-11$ & 0.1007 & $4.31 \mathrm{E}-15$ \\
\hline 70 & 0.9890 & $3.90 \mathrm{E}-11$ & 1.1933 & $3.90 \mathrm{E}-11$ & 0.1225 & $1.36 \mathrm{E}-14$ \\
\hline 80 & 0.9882 & $5.57 \mathrm{E}-11$ & 1.1732 & $5.57 \mathrm{E}-11$ & 0.1468 & $4.04 \mathrm{E}-14$ \\
\hline 90 & 0.9863 & $1.18 \mathrm{E}-10$ & 1.1204 & $1.18 \mathrm{E}-10$ & 0.2101 & $4.28 \mathrm{E}-13$ \\
\hline 95 & 0.9836 & $2.97 \mathrm{E}-10$ & 1.0442 & $2.97 \mathrm{E}-10$ & 0.3179 & $1.15 \mathrm{E}-11$ \\
\hline 98 & 0.9786 & $1.12 \mathrm{E}-09$ & 0.9246 & $1.12 \mathrm{E}-09$ & 0.5580 & $1.00 \mathrm{E}-08$ \\
\hline 99 & 0.9740 & $2.98 \mathrm{E}-09$ & 0.8385 & $2.98 \mathrm{E}-09$ & 0.8104 & $1.10 \mathrm{E}-04$ \\
\hline
\end{tabular}

Considering Table $4 \mathrm{a}$ and by observing the values of $\mathrm{R}^{2}$ and the significances of all the coefficients, it can be said that the data fitted the equation model very well. The value $\alpha$ increases with the RHs and this signifies the increase in the dominance of fine/accumulation particles, but at deliquescence point (98-99\%) $\mathrm{RH}$ it is less than 1 this shows the presence of coarse mode particles as fine mode are act as cloud condensation nuclei. But $\beta$ (turbidity coefficient) increase with the increase in RHs indicating that the aerosol loading also increases with the increase in RH.

Table 4b: Quadratic results of the regression analysis for model 4 of table 1

\begin{tabular}{|l|l|l|l|l|l|l|l|l|}
\hline $\mathrm{RH}(\%)$ & $\mathrm{R}^{2}$ & Sig & $\alpha_{1}$ & Sig & $\alpha_{2}$ & Sig & $\beta$ & Sig \\
\hline 0 & 0.9999 & $4.24 \mathrm{E}-18$ & -1.7485 & $6.02 \mathrm{E}-14$ & -0.3471 & $1.75 \mathrm{E}-09$ & 0.0575 & $4.46 \mathrm{E}-20$ \\
\hline 50 & 0.9999 & $1.11 \mathrm{E}-19$ & -1.7883 & $1.32 \mathrm{E}-15$ & -0.3708 & $2.68 \mathrm{E}-11$ & 0.0844 & $4.37 \mathrm{E}-21$ \\
\hline 70 & 1.0000 & $2.00 \mathrm{E}-20$ & -1.7890 & $2.13 \mathrm{E}-16$ & -0.3809 & $3.44 \mathrm{E}-12$ & 0.1022 & $1.46 \mathrm{E}-21$ \\
\hline 80 & 1.0000 & $6.33 \mathrm{E}-21$ & -1.7807 & $6.07 \mathrm{E}-17$ & -0.3885 & $7.90 \mathrm{E}-13$ & 0.1220 & $8.24 \mathrm{E}-22$ \\
\hline 90 & 1.0000 & $6.10 \mathrm{E}-22$ & -1.7469 & $4.63 \mathrm{E}-18$ & -0.4007 & $3.86 \mathrm{E}-14$ & 0.1735 & $2.75 \mathrm{E}-22$ \\
\hline 95 & 1.0000 & $6.62 \mathrm{E}-23$ & -1.6855 & $3.73 \mathrm{E}-19$ & -0.4101 & $1.83 \mathrm{E}-15$ & 0.2614 & $1.77 \mathrm{E}-22$ \\
\hline 98 & 1.0000 & $4.21 \mathrm{E}-23$ & -1.5742 & $1.50 \mathrm{E}-19$ & -0.4155 & $3.55 \mathrm{E}-16$ & 0.4576 & $4.98 \mathrm{E}-21$ \\
\hline 99 & 1.0000 & $1.22 \mathrm{E}-22$ & -1.4901 & $3.03 \mathrm{E}-19$ & -0.4167 & $4.26 \mathrm{E}-16$ & 0.6642 & $2.08 \mathrm{E}-18$ \\
\hline
\end{tabular}

As indicated by Table $4 \mathrm{~b}$ and by observing the values of $\mathrm{R}^{2}$ and the significances of all the coefficients, it can be said that the data fitted the equation model very well. The negative sign of $\alpha_{2}$, shows that this is monomodal and is dominated by fine mode particles. The increase in the values of $\alpha_{2}$, with RH shows the increase in the concentrations of fine particles. But $\beta$ (turbidity coefficient) increase with the increase in $\mathrm{RH}$ indicating that the aerosol loading also increases with the increase in RH.

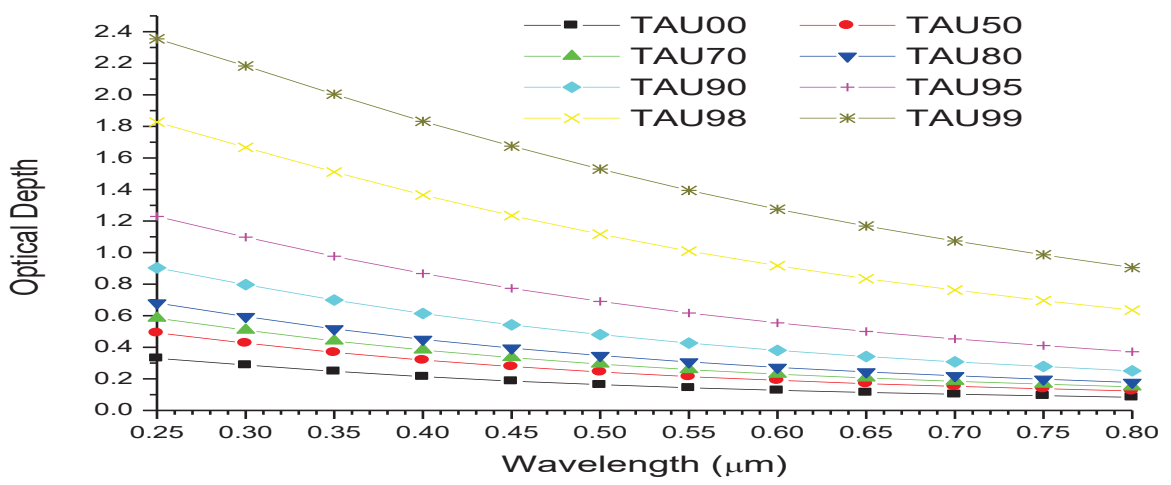

Figure 4(a). A graph of optical depth against wavelength for continental average

From the plots of figure $4 \mathrm{a}$, it can seen that the optical depth increase with increase in RHs, but relative humidities decreases at longer wavelength though increases as the number density of water soluble increases, indicating more scattering in the forward direction verifying the effect of cooling. 


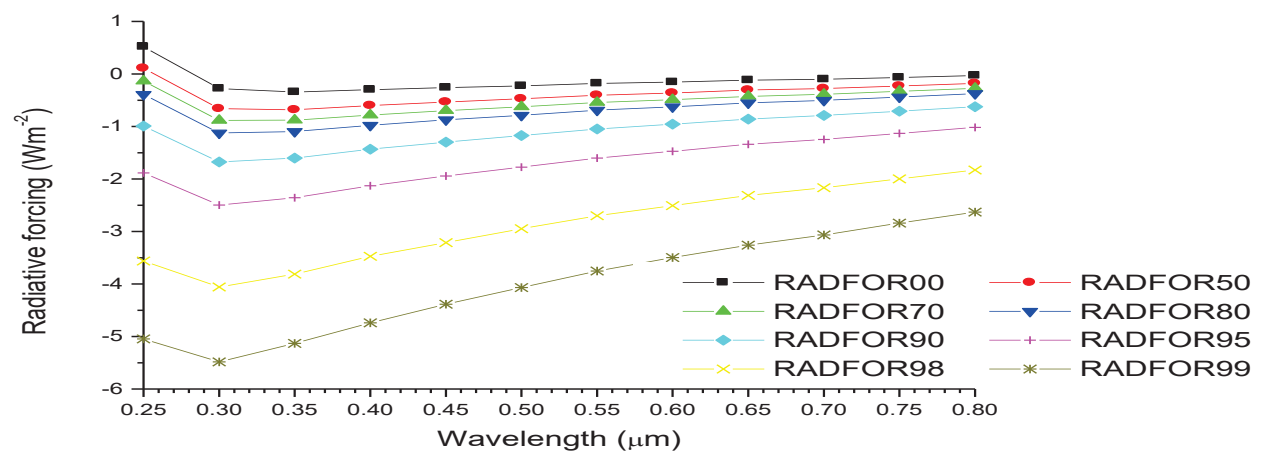

Figure 4(b). A graph of radiative forcing against wavelength for continental average.

From the plots of figure $4 \mathrm{~b}$, the warming effects occurred at $0-50 \%$ RHs. While cooling begins to occur at $70 \%$ and increase with increase in relative humidities and this show that water soluble due to high percentage of sulphate has a relatively high scattering coefficient.

Table 5a: Linear results of the regression analysis for model 5 of table 1

\begin{tabular}{|l|l|l|l|l|l|l|}
\hline RH(\%) & $R^{2}$ & Sig & $\alpha$ & Sig & $\beta$ & Sig \\
\hline 0 & 0.9910 & $1.49 \mathrm{E}-11$ & 1.2075 & $1.49 \mathrm{E}-11$ & 0.0685 & $5.06 \mathrm{E}-16$ \\
\hline 50 & 0.9898 & $2.67 \mathrm{E}-11$ & 1.2093 & $2.67 \mathrm{E}-11$ & 0.1018 & $4.57 \mathrm{E}-15$ \\
\hline 70 & 0.9890 & $3.97 \mathrm{E}-11$ & 1.1940 & $3.97 \mathrm{E}-11$ & 0.1239 & $1.47 \mathrm{E}-14$ \\
\hline 80 & 0.9882 & $5.71 \mathrm{E}-11$ & 1.1738 & $5.71 \mathrm{E}-11$ & 0.1486 & $4.42 \mathrm{E}-14$ \\
\hline 90 & 0.9863 & $1.19 \mathrm{E}-10$ & 1.1207 & $1.19 \mathrm{E}-10$ & 0.2127 & $4.68 \mathrm{E}-13$ \\
\hline 95 & 0.9835 & $3.02 \mathrm{E}-10$ & 1.0444 & $3.02 \mathrm{E}-10$ & 0.3220 & $1.31 \mathrm{E}-11$ \\
\hline 98 & 0.9785 & $1.14 \mathrm{E}-09$ & 0.9245 & $1.14 \mathrm{E}-09$ & 0.5654 & $1.28 \mathrm{E}-08$ \\
\hline 99 & 0.9738 & $3.06 \mathrm{E}-09$ & 0.8382 & $3.06 \mathrm{E}-09$ & 0.8215 & $1.92 \mathrm{E}-04$ \\
\hline
\end{tabular}

Based on the contents of Table $5 \mathrm{a}$ and by observing the values of $\mathrm{R}^{2}$ and significances of all the coefficients, it can be said that the data fitted the equation model very well. The value $\alpha$ increases with the RHs and this signifies the increase in the dominance of fine/accumulation particles, but at deliquescence point (98-99\%) RH it is less than 1 signifies the presence of coarse mode particles as fine mode are act as cloud condensation nuclei. But $\beta$ (turbidity coefficient) increase with the increase in RHs indicating that the aerosol loading also increases with the increase in RH.

Table 5b: Quadratic results of the regression analysis for model 5 of table 1

\begin{tabular}{|l|l|l|l|l|l|l|l|l|}
\hline RH(\%) & $\mathrm{R}^{2}$ & Sig & $\alpha_{1}$ & Sig & $\alpha_{2}$ & Sig & $\beta$ & Sig \\
\hline 0 & 0.9999 & $4.71 \mathrm{E}-18$ & -1.7514 & $6.67 \mathrm{E}-14$ & -0.3478 & $1.93 \mathrm{E}-09$ & 0.0580 & $5.16 \mathrm{E}-20$ \\
\hline 50 & 0.9999 & $8.41 \mathrm{E}-20$ & -1.7899 & $1.00 \mathrm{E}-15$ & -0.3713 & $2.03 \mathrm{E}-11$ & 0.0853 & $3.47 \mathrm{E}-21$ \\
\hline 70 & 1.0000 & $1.48 \mathrm{E}-20$ & -1.7912 & $1.57 \mathrm{E}-16$ & -0.3819 & $2.50 \mathrm{E}-12$ & 0.1033 & $1.13 \mathrm{E}-21$ \\
\hline 80 & 1.0000 & $4.22 \mathrm{E}-21$ & -1.7832 & $4.01 \mathrm{E}-17$ & -0.3897 & $5.14 \mathrm{E}-13$ & 0.1234 & $5.79 \mathrm{E}-22$ \\
\hline 90 & 1.0000 & $6.77 \mathrm{E}-22$ & -1.7477 & $5.13 \mathrm{E}-18$ & -0.4010 & $4.26 \mathrm{E}-14$ & 0.1757 & $3.27 \mathrm{E}-22$ \\
\hline 95 & 1.0000 & $7.36 \mathrm{E}-23$ & -1.6867 & $4.13 \mathrm{E}-19$ & -0.4108 & $2.01 \mathrm{E}-15$ & 0.2646 & $2.14 \mathrm{E}-22$ \\
\hline 98 & 1.0000 & $4.65 \mathrm{E}-23$ & -1.5758 & $1.64 \mathrm{E}-19$ & -0.4165 & $3.83 \mathrm{E}-16$ & 0.4635 & $6.37 \mathrm{E}-21$ \\
\hline 99 & 1.0000 & $1.67 \mathrm{E}-22$ & -1.4912 & $4.10 \mathrm{E}-19$ & -0.4176 & $5.69 \mathrm{E}-16$ & 0.6731 & $3.81 \mathrm{E}-18$ \\
\hline
\end{tabular}

From Table $5 \mathrm{~b}$ and by observing the values of $\mathrm{R}^{2}$ and the significances of all the coefficients, it can be said that the data fitted the equation model very well. The negative sign of $\alpha_{2}$, shows that this is monomodal and is dominated by fine mode particles. The increase in the values of $\alpha_{2}$, with RH shows the increase in the concentrations of fine particles. But $\beta$ (turbidity coefficient) increase with the increase in RH indicating that the aerosol loading also increases with the increase in $\mathrm{RH}$. 


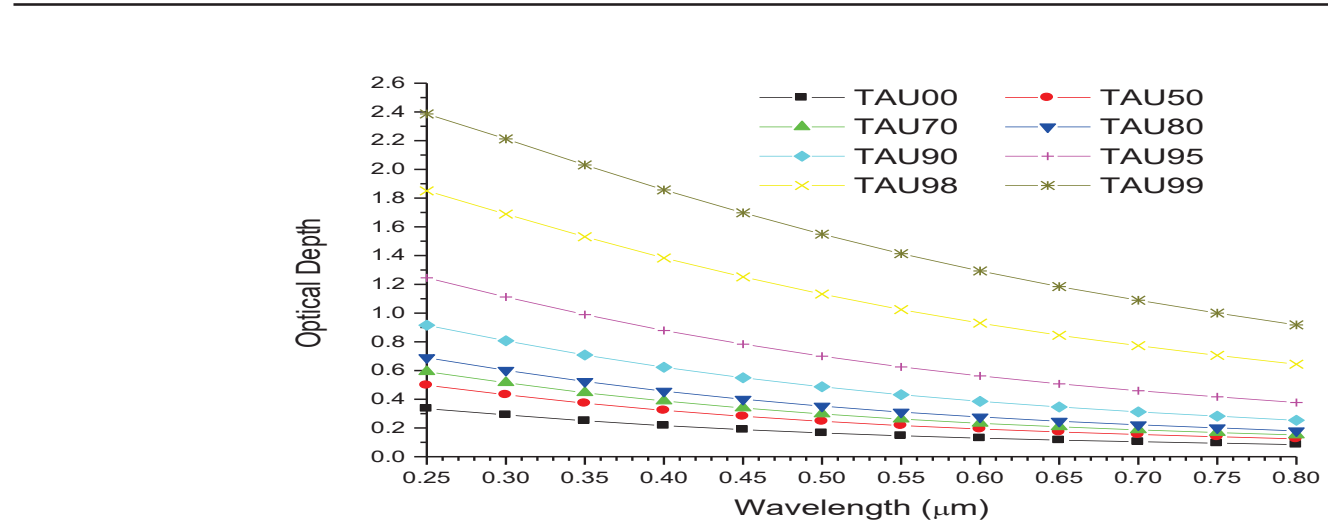

Figure 5(a). A graph of optical depth against wavelength for continental average.

From the plots of figure 5a, it can be seen that the optical depth increase with increase in RHs, but relative humidities decreases at longer wavelength though increases as the number density of water soluble increases, indicating more scattering in the forward direction verifying the effect of cooling.

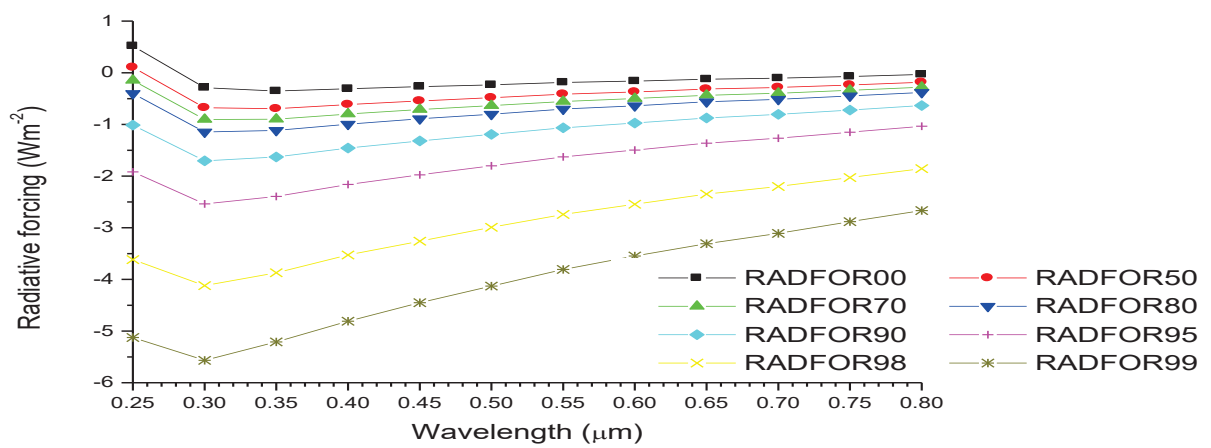

Figure 5(b). A graph of radiative forcing against wavelength for continental average.

From the plots of figure $5 \mathrm{~b}$, the warming effects occurred at $0-50 \%$ RHs. While cooling begins to occur at $70 \%$ and increase with increase in relative humidities and this show that water soluble due to high percentage of sulphate has a relatively high scattering coefficient.

\section{Conclusion}

From the analysis of the data, it can be concluded that Angstrom exponent can be used to determine the most dominant type of aerosols. The analysis of Radiative forcing and Optical depth verify that the water-soluble components of Continental average aerosols reflects cooling effect, therefore, has a relatively high scattering coefficient. The $\alpha$ and $\alpha_{2}$ shows that Earth's atmosphere is composed of dominant Fine/accumulation mode particles in the continental region, the turbidity, $\beta$, increases with increase in RHs indicating that the aerosol loading also increases with the increase in $\mathrm{RH}$ and visibility of atmosphere reduces. The data clearly demonstrates that an extremely large fraction of fine/accumulation modes aerosols in turbid atmosphere mainly caused by local anthropogenic pollution or biomass aerosols transport from forest fire. The analysis showed that the inclusion of the curvature (polynomial fit of $\ln \tau$ with respect to $\ln \lambda$ ) significantly improve the aerosol type discrimination whether monomodal or bimodal as found by (Eck et al., 1999; Reid et al., 1999; Schuster et al., 2006). In our case the $\alpha_{2}$ (curvature) is negative at all RHs, this shows that Earth's atmosphere is composed of dominant Fine/accumulation mode particles in the continental average aerosols.

\section{References}

Angstrom A.K. (1929). On the atmospheric transmission of sun radiation and on dustin the air, Geogr. Ann., 11, $156-166$.

Angstrom, A. ( 1961). Techniques of Determining the Turbidity of the At-mosphere, Tellus, 13, $214-223$.

Charlson, R. J., Schwartz, S. E., Hales, J. M., Cess, R. D.,Coakley, J. A., Hansen, J. E. and Hoffmann, D. J (1992). Climate forcing by anthropogenic aerosols, Science, 255423430.

Chylek, P. and Wong, J. (1995). Effect of absorbing aerosols on global radiation budget. Geophysical Research Letters 22 929-931

Eck, T. F., Holben, B. N., Reid, J. S., Dubovik, O., Smirnov, A., O’Neill, N. T., Slutsker, I and Kinne, S. (1999). Wavelength Dependence of the Optical Depth of Biomass burning, Urban and desert dust Aerosols. Journal 
of Geophysical Research 104 333-349.

Hess M., Koepke P., \& Schult. (1998). Optical properties of aerosols and Cloud: Software package OPAC., Munchen, Germany.

Intergovernmental Panel on Climate Change (2007). Climate Change 2007: The Physical Science Basis: Contribution of Working Group I to the Fourth Assessment Report of the Intergovernmental Panel on Climate Change, edited by S. Solomon et al., Cambridge Univ. Press, Cambridge, U. K.

King, M.D. and Byrne, D.M. (1976). A Method for Inferring Total Ozone Content from Spectral Variation of Total Optical Depth Obtained with a Solar Radiometer. Journal of the Atmospheric Sciences, 33, 2242-2251. http://dx.doi.org/10.1175/1520-0469(1976)033<2242:AMFITO>2.0.CO;2

Liou, K.N. (2002). An Introduction to Atmospheric Radiation. Elsevier, New York, 583 p

Penner, J.E., Dickinson, R.E. and O’Neil, C.A. (1992) Effects of Aerosol from Biomass Burning on the Global Radiation Budget. Science, 256, 1432-1434. http://dx.doi.org/10.1126/science.256.5062.1432

Segan, C. and Pollack, J. (1967). Anisotropic Non-Conservative Scattering and the Clouds of Venus. Journal of Geophysical Research, 72, 469-477. http://dx.doi.org/10.1029/JZ072i002p00469

O’Neill, N. T and Royer, A. (1993). Extraction of binomial aerosol-size distribution Radii from spectral and angular slope (Ångström) coefficients Appl. Opt. 32 1642-1645

Tijjani B. I, Shaaibu .F \& Aliyu. A. (2014). Effect of relative humidity on maritime polluted aerosols, J. pure and applied phys, 2, 9-36.

Zieger, P., Fierz-Schmidhauser, R., Weingartner, E., \& Baltensperger, U. (2013). Effects of relative humidity on aerosol light scattering: results from different European sites, Atmos. Chem. Phys., 13, 10609-10631, doi:10.5194/acp-13-10609

Verma, S., Boucher, O., Shekar Reddy, M., Upadhaya, H.C., Le Van, P., Binkowski, F.S and Sharma, O. P. (2012). Tropospheric distribution of sulphate aerosols Mass and number concentration during INDOEX-IFP and its transport over the Indian ocean:a GCM study,mAtmospheric Chemistry and Physics, 12, 6185-6196.

Kiehl, J. T and Briegleb, B. P. (1993). The relative roleof sulphate aerosols and greenhouse gases in climate forcing. Science, 260, 311-314.

Seinfeld, J. and Pandis, S. (2006). Atmospheric Chemistry and Physics: From Air Pollution to Climate Change, John Wiley and Sons, Inc., Hoboken, New Jersey,

Lohmann, U. and Leck, C. (2005). Importance of submicron surface-active organic aerosols for pristine Arctic clouds, Tellus B, 57, 261-268,

Ramaswamy, V., Boucher, O., Haigh, J., Hauglustaine, D., and Haywood, J. (2001). Radiative Forcing of Climate Change, Cambridge University Press, Cambridge, United Kingdom and New York, NY, USA.

Twomey, S. (1977). Atmospheric Aerosols, Developments in Atmospheric Science, Elsevier, New York, USA. 